15 White $\mathrm{H}$. A heteroskedasticity-consistent covariance matrix estimator and a direct test for heteroskedasticity. Econometria 1980;48:817-30. 16 Paffenbarger RS, Lee IM, Hsieh CC. Exercise intensity and longevity in men. JAMA 1995;273:1179-84.

17 Wilson P, Paffenbarger R, Morris J, Havlik R. Assessment methods for physical activity and physical fitness studies. Am J Heart 1986;111:117792.

18 Morgan K, Clarke D. Customary physical activity and survival in later life: a study in Nottingham UK. J Epidemiol Community Health 1997;51:490-3.

19 Bowling A. Social support and social networks: their relationship to the successful and unsuccessful survival of elderly people in the community. An analysis of concepts and a review of the evidence. Fam Pract 1991:8:68-83.

20 Idler EL, Benyamini Y. Self-rated health and mortality: a review of twenty-seven community studies. J Health Soc Behav 1997;38:21-37.

21 Atkins P, Ogle S, Finegan T, Shenfield G. Influence of "academic detailing" on prescribing for elderly patients. Health Promotion J Aust 1996;6:14-20.

22 LaCroix A, Leveille S, Hecht J, Grothaus L, Wagner EH. Does walking decrease the risk of cardiovascular disease hospitalizations and death in older adults? J Am Geriatr Soc 1996;44:113-20.

23 Schmidt RM. HEALTH WATCH: health promotion and disease prevention in primary care. Methods Inf Med 1993;32:245-8.

24 Williams $\mathrm{P}$, Lord S. Effects of group exercise on cognitive functioning and mood in older women. Aust NZ J Public Health 1997:21:45-52.

25 Hamdorf PA, Withers RT, Penhall RK, Plummer J. A follow-up study on the effects of training on the fitness and habitual activity patterns of 60 to 70 year old women. Arch Phys Med Rahabil 1993;74:473-7.

26 Hillsdon M, Thorogood M, Anstiss T, Morris J. Randomised controlled trials of physical activity promotion in free living populations: a review. J Epidemiol Community Health 1995;49:448-53.

27 Cupples M, McKnight A. Randomised controlled trial of health promotion in general practice for patients at high cardiovascular risk. BMJ 1994:309:993-6.

28 Imperial Cancer Research Fund OXCHECK Study Group. Effectiveness of health checks condusted by nurses in primary care: final results of the OXCHECK study. BMJ 1995;310:1099-104.

(Accepted 2 June 1999)

\title{
Five year follow up of patients at high cardiovascular risk who took part in randomised controlled trial of health promotion
}

\author{
M E Cupples, A McKnight
}

Health promotion programmes for patients with coronary heart disease are valuable, ${ }^{12}$ but there is little evidence on their lasting effect. ${ }^{3}$ A randomised controlled trial in which patients who received personalised health promotion for two years showed significant benefits in lifestyle and quality of life. ${ }^{2}{ }^{4} \mathrm{We}$ investigated whether the differences in lifestyle, quality of life, and risk factors persisted between the two groups five years after enrolment.

\section{Participants, methods, and results}

Patients aged under 75 who had had angina (all grades included) for at least six months and no other concurrent serious illness were identified by 18 general practices in Belfast. Their diagnosis was confirmed at interview, and they were randomly allocated to receive either usual NHS care and personal health promotion from a trained nurse every four months for two years or usual NHS care alone. Sealed envelopes opened at interview showed group allocations. Both groups were reviewed after two years. Full details, including sample size calculations, have been reported previously. ${ }^{2}$

Patients who completed the study were invited by letter to a five year follow up interview at their general practice surgery or their home. The nurse, blind to the trial group allocation, administered a questionnaire; measured height, weight, blood pressure, and breath carbon monoxide concentration; and took a blood sample for measurement of serum cholesterol concentration. Patients completed a Nottingham health profile questionnaire.

Distributions of age (mean 63 (SD 7)), sex (59\% (408/688) male), and social class (I and II, 11\% (72/688); III, 47\% (325/688); IV and V, 42\% (291/688) were similar in both groups. After five years 250 of the $342(73 \%)$ in the intervention group (45 defaulted, 47 had died) and 237 of the $346(68 \%)$ in the non-intervention group (44 defaulted, 65 had died) were reviewed.

There were no significant differences between the groups in respect of blood pressure, serum cholesterol concentration, body mass index, reported frequency of angina, or restriction of activities at five years (table).

Differences between the groups both in mean reported exercise frequency and change of frequency were significant at two years $(\mathrm{P}<0.001)$. The difference in change of frequency was significant at five years $(\mathrm{P}<0.05)$. The non-intervention group reported a progressive decrease in exercise frequency over five years. The intervention group's mean exercise frequency had increased at two years but decreased subsequently.

At two years the intervention group's reported diet was better than and had improved significantly compared with that of the non-intervention group, but there were no significant differences between groups at five years. Differences between groups in mean quality of life scores at various times were not significant. The intervention group's score for social isolation showed improvement at two years but not at five years.

Initially there was no significant difference between groups in the proportion of patients who took drugs (glyceryl trinitrate, nifedipine) to prevent an angina episode; a greater proportion of the intervention group did so at both two and five years (131/250 (52\%) v $94 / 237(40 \%) ; \mathrm{P}<0.001)$ and five years $(119 / 250$ $(48 \%)$ v $91 / 237(38 \%) ; \mathrm{P}<0.05)$. Smoking cessation (self report validated by measurement of breath carbon monoxide concentration) was not significantly different between groups at five years $(7 / 41(17 \%)$ in the intervention group; $13 / 51 \quad(25 \%)$ in the nonintervention group).

We also analysed the data on an intention to treat basis, with baseline or adjusted values being substituted for missing data, but this did not alter the conclusions.
Department of General Practice, Queen's University, Belfast BT9 7HR

M E Cupples senior lecturer in general practice

Northern Ireland Council for Postgraduate Medical and Dental Education, Belfast BT7 3JH

A McKnight director of general practice

Correspondence to: M E Cupples m.cupples@qub.ac.uk

BMJ 1999;319:687-8 
Mean values of variables at baseline and two year and five year follow up for those who completed study

\begin{tabular}{|c|c|c|c|c|c|c|c|}
\hline \multirow[b]{2}{*}{ Variable } & \multirow[b]{2}{*}{ No } & \multicolumn{2}{|r|}{ At baseline } & \multicolumn{2}{|c|}{ At 2 year follow up } & \multicolumn{2}{|c|}{ At 5 year follow up } \\
\hline & & Mean & $\begin{array}{l}\text { Mean difference } \\
\text { between groups } \\
(95 \% \mathrm{Cl})\end{array}$ & Mean & $\begin{array}{l}\text { Mean difference } \\
\text { between groups } \\
(95 \% \mathrm{CI})\end{array}$ & Mean & $\begin{array}{l}\text { Mean difference } \\
\text { between groups } \\
(95 \% \mathrm{CI})\end{array}$ \\
\hline \multicolumn{8}{|c|}{ Systolic pressure (mm Hg) } \\
\hline Intervention & 250 & 137.5 & $0.5(-3.5$ to 4.5$)$ & 137.1 & $2.0(-1.8$ to 5.7$)$ & 144.8 & $-0.8(-5.2$ to 3.5$)$ \\
\hline Non-intervention & 237 & 137.0 & & 135.2 & & 145.6 & \\
\hline \multicolumn{8}{|c|}{ Diastolic pressure (mm Hg) } \\
\hline Intervention & 250 & 83.1 & $0.5(-1.8$ to 2.9$)$ & 77.4 & $0.4(-1.5$ to 2.4$)$ & 74.5 & $-1.3(-3.6$ to 1.0$)$ \\
\hline Non-intervention & 237 & 82.6 & & 77.0 & & 75.8 & \\
\hline \multicolumn{8}{|c|}{ Serum cholesterol (mmol/l) } \\
\hline Intervention & 250 & 6.29 & $0.21(0.01 \text { to } 0.40)^{*}$ & 6.15 & $0.09(-0.10$ to 0.28$)$ & 5.94 & $0.06(-0.15$ to 0.26$)$ \\
\hline Non-intervention & 237 & 6.09 & & 6.05 & & 5.88 & \\
\hline \multicolumn{8}{|l|}{ Body mass index } \\
\hline Intervention & 250 & 27.4 & $0.2(-0.6$ to 1.0$)$ & 26.9 & $0.3(-0.5$ to 1.1$)$ & 27.0 & $0.2(-0.6$ to 1.0$)$ \\
\hline Non-intervention & 237 & 27.2 & & 26.6 & & 26.8 & \\
\hline \multicolumn{8}{|c|}{ No of episodes of angina per week } \\
\hline Intervention & 250 & 3.3 & $0.9(0.1 \text { to } 1.6)^{\star}$ & 2.7 & $0.7(0.1 \text { to } 1.4)^{\star}$ & 2.6 & $0.1(-0.7$ to 1.0$)$ \\
\hline Non-intervention & 237 & 2.4 & & 2.0 & & 2.5 & \\
\hline \multicolumn{8}{|c|}{ Physical exercise (score based on № of 20 minute episodes per week) } \\
\hline Intervention & 250 & 3.6 & $-0.2(-0.5$ to 0.1$)$ & 4.0 & $0.7(0.4 \text { to } 1.0)^{\star \star \star} t \mathrm{tt}$ & 3.0 & $0.2 \dagger(-0.2$ to 0.5$)$ \\
\hline Non-intervention & 237 & 3.8 & & 3.2 & & 2.8 & \\
\hline \multicolumn{8}{|c|}{ Diet (score based on frequency of eating certain foodsł; higher score=better diet) } \\
\hline Intervention & 250 & 21.1 & $0.0(-0.8$ to 0.8$)$ & 23.7 & $1.6(0.9 \text { to } 2.4)^{\star \star \star}+t \dagger$ & 22.6 & $0.4(-0.3$ to 1.2$)$ \\
\hline Non-intervention & 237 & 21.1 & & 22.1 & & 22.2 & \\
\hline \multicolumn{8}{|c|}{ Nottingham health profile questionnaire (score)币 } \\
\hline \multicolumn{8}{|l|}{ Emotion: } \\
\hline Intervention & 181 & 19.4 & $-0.4(-5.5$ to 4.7$)$ & 19.8 & $0.0(-5.2$ to 5.2$)$ & 19.0 & $-2.1(-7.5$ to 3.3$)$ \\
\hline Non-intervention & 169 & 19.8 & & 19.8 & & 21.1 & \\
\hline \multicolumn{8}{|l|}{ Energy: } \\
\hline Intervention & 181 & 39.7 & $2.1(-5.7$ to 10.0$)$ & 41.9 & 0.5 (-7.8 to 8.8$)$ & 40.6 & $-4.7(-13.2$ to 3.7$)$ \\
\hline Non-intervention & 169 & 37.5 & & 41.4 & & 45.4 & \\
\hline \multicolumn{8}{|l|}{ Mobility: } \\
\hline Intervention & 181 & 20.8 & $2.8(-1.6$ to 7.1$)$ & 21.9 & $-0.4(-5.2$ to 4.5$)$ & 24.3 & $-1.3(-6.3$ to 3.6$) \dagger$ \\
\hline Non-intervention & 169 & 18.0 & & 22.3 & & 25.7 & \\
\hline \multicolumn{8}{|l|}{ Pain: } \\
\hline Intervention & 181 & 17.5 & $1.8(-2.8$ to 6.4$)$ & 18.0 & $0.5(-4.7$ to 5.6$)$ & 19.0 & $-3.4(-9.2$ to 2.3$) \dagger$ \\
\hline Non-intervention & 169 & 15.7 & & 17.5 & & 22.4 & \\
\hline \multicolumn{8}{|l|}{ Sleep: } \\
\hline Intervention & 181 & 35.5 & $-1.1(-8.0$ to 5.9$)$ & 36.8 & $3.0(-4.0$ to 9.9$)$ & 34.4 & $-2.4(-9.3$ to 4.5$)$ \\
\hline Non-intervention & 169 & 36.5 & & 33.8 & & 36.8 & \\
\hline \multicolumn{8}{|l|}{ Social isolation: } \\
\hline Intervention & 181 & 11.3 & $1.7(-2.6$ to 5.9$)$ & 10.3 & $-2.2(-6.6 \text { to } 2.1)^{\star}$ & 11.8 & $0.0(-4.3$ to 4.3$)$ \\
\hline Non-intervention & 169 & 9.7 & & 12.6 & & 11.8 & \\
\hline
\end{tabular}

${ }^{*} \mathrm{P}<0.05$, ${ }^{* *} \mathrm{P}<0.001$ : differences between groups in mean values at each time were compared by $t$ tests; differences in frequencies were compared by $\chi^{2}$ test. t† $P<0.001, \dagger P<0.05$ for differences in the extent of change in individuals within each group in comparisons between groups for each variable for baseline to 2 year follow up and baseline to 5 year follow up using $t$ tests. Two tailed probability testing was used throughout.

$\ddagger$ Poultry, green vegetables, fruit, high fibre foods, red meat, biscuits, and fried food.

IBaseline scores for 67 patients from each group were not valid and three patients did not complete the questionnaire at five years; these patients did not differ significantly from the remainder of the sample in any baseline measurement or characteristic.

\section{Comment}

Three years after the end of a personalised health promotion programme based in primary care for patients with angina most of the benefits identified at the end of two years had worn off. At the end of five years, benefits reported in respect of exercise and taking drugs prophylactically were still evident but smaller. The results suggest that prolonged provision of health promotion for patients may be desirable and support the recommendation that secondary prevention in coronary heart disease should be a healthcare priority. ${ }^{5}$

We thank all the patients and general practitioners who participated in the study, the research nurses at each stage, and $\mathrm{Mr}$ Mike Stevenson of the Health and Social Care Research Unit, Queen's University of Belfast, for statistical advice.

Contributors: MC and AMcK designed the study. MC was responsible for collecting the data, interpretation, and reporting.
AMcK contributed to the interpretation and reporting. Both authors are guarantors.

Funding: Northern Ireland Chest, Heart and Stroke Association.

Competing interests None declared.

1 Campbell NC, Thain J, Deans HG, Ritchie LD, Rawles JM, Squait JL. Secondary prevention clinics for coronary heart disease: randomised trial of effect on health. BMJ 1998;316:1334-7.

2 Cupples ME, McKnight A. Randomised controlled trial of health promotion in general practice for patients at high cardiovascular risk. BMJ 1994;309:993-6

3 NHS Centre for Reviews and Dissemination, University of York. Cardiac rehabilitation. Effective Health Care 1998;4:7-9.

4 Cupples ME, McKnight A, O'Neill C, Normand C. The effect of personal health education on the quality of life of patients with angina in general practice. Health Educ J 1996;55:75-83.

5 Ebrahim S, Davey Smith G. Systematic review of randomised controlled trials of multiple risk factor interventions for preventing coronary heart disease. BMJ 1997;314:1666-74.

(Accepted 20 May 1999) 